\title{
Optimization Of Region Of Interest (ROI) Image Of Malaria Parasites
}

\author{
Rika Rosnelly*1, Linda Wahyuni ${ }^{2}$ \\ 1,2Universitas Potensi Utama, Engineering and Computer Sciences Faculty \\ *1rikarosnelly@gmail.com, 2linda@potensi-utama.ac.id \\ *Corresponding author \\ Jani Kusanti ${ }^{3}$ \\ Universitas Surakarta, Electrical Engineering and Informatics Faculty \\ janikusanti@yahoo.co.id
}

\begin{abstract}
Abstrak: The stage of region of interest (ROI) is the determining part to the next stage in image processing. $R O I$ is a process of taking certain parts or regions in an image. ROI can be done by manual and automatic cropping. Some previous studies still use cropping manually for detection of malaria parasites. This study uses cropping automatically for detection of malaria parasites. The types of malaria parasites used were falciparum, vivax and malariae with ring stages, tropozoite, schizon and gametocytes. Data from malaria parasites were obtained at the North Sumatra Provincial Health Laboratory. The results show that the ROI image can crop the malaria parasite region.
\end{abstract}

Keywords - malaria parasite, ROI.

\section{INTRODUCTION}

Malaria is a disease that can cause death. According to the WHO record for malaria sufferers that claimed the lives of more than 400 thousand people every year. This disease is widely experienced in tropical and sub-tropical regions, including sub-Sahara Africa, Asia, and Latin America. [1]. According to data from the Ministry of Health in Indonesia in 2017, particularly Papua, West Papua and East Nusa Tenggara are among the high endemic areas and are recorded at around $90 \%$ for the spread of malaria [2]. Ministry of Health data in 2017 recorded 261,617 cases of malaria, the death toll ranged from 100 people [3].

Research on many images performs the cropping process at the beginning of image processing. Cropping is done to get the desired image in the identification process. The accuracy in the cropping image process is very important to determine the results of subsequent processing. ROI boundaries are used so that each object that will be detected as a certain classification so that the object being examined is in accordance with what is expected. In some previous studies, identification was carried out from the ROI image. Research [4] [5] images used ROI results to identify malaria parasites. In both studies using manual ROI images, this allows for a number of parasite images of blood smears that have been missed. In a previous study also stated that the image processing which is an important problem is how to extract to find features from the image, several studies related to features used to analyze types of malaria parasites with shape features are [6] [7] [8] [9] [10] [11] [12], color and texture are studies [13], color and shape are research [14], shape, color, and texture are studies [15] [4] [5]. From these studies, it can be seen that it becomes important to get ROI image results in one blood smear so that the results of the level of accuracy obtained in subsequent processing become increased. 


\section{LITERATURE REVIEW}

The following are the results of a review of several papers in journals, proceedings that discuss the examination of malaria types based on the region of interest (ROI). Many studies use the digital image to identify malaria. Each study has different types of image characteristics. This results in different methods for the region of interest.

The study [16] used ROI with manual cropping in conducting research on the classification of Plasmodium falciparum images causing malaria in human red blood cells using the multiclass Support Vector Machine (SVM) method.

Research [17] using manual cropping conducted research on the development of the classification system of malaria stage Plasmodium falciparum trophozoite stage, schizon and gametocytes in microscopic images of blood cells using Multi-Layer Perceptron.

Research [18] regarding automatic quantification and classification of malaria parasites on thin blood smear. This study presents an approach to automatically measure and classify infected red blood cells in Plasmodium vivax trophozoite stage in thin blood smears. In this paper proposes a method for distinguishing infected red blood cells and healthy red blood cells. This research carried out at the stage of the segmentation process dilation and erosion was carried out to remove the background element. To remove a smaller image, biner morphology open partner surgery is used. Each element has a smaller size than the object that was deleted. In this study, only one sample of malaria parasite was used, namely vivax with trophozoite stage, where the characteristics of vivax malaria had a larger size than red blood cells. The sample image that was shown also had no white blood cell object where the size of the white blood cell was greater than the malaria parasite.

The research [19] at the segmentation stage carried out the process of taking malaria parasites using filtering for malaria diagnosis based on screening and computer visualization of the vision area of the trophozoite plasmodium falciparum stage on blood smears.

In the study [20] regarding the recent progress of malaria parasite detection system based on mathematical morphology, [21] wrote at the segmentation stage using adaptive thresholding, then carried out erosion and dilation processes to detect malaria parasites. [22] wrote at the segmentation stage using watershed, to detect malaria parasites. The research [23] segmentation stage uses adaptive thresholding and closing and uses elliptical mathematical morphology with size $=3$ to identify malaria parasites falciparum, vivax, malaria, ovale infected or not infected.

Research conducted is at the ROI stage using automatic cropping with image morphology that is area and perimeter to retrieve malaria parasite areas. The types of malaria parasites used in this study were falciparum, vivax and malaria along with the stages namely rings, trophozoites, schizon and gametocytes.

\section{RESEARCH METHOD}

System development model Identification of malaria and the stages based on digital image processing conducted in this study is to get the results of cropping automatically an image of malaria parasite types can be seen in Figure 1. 


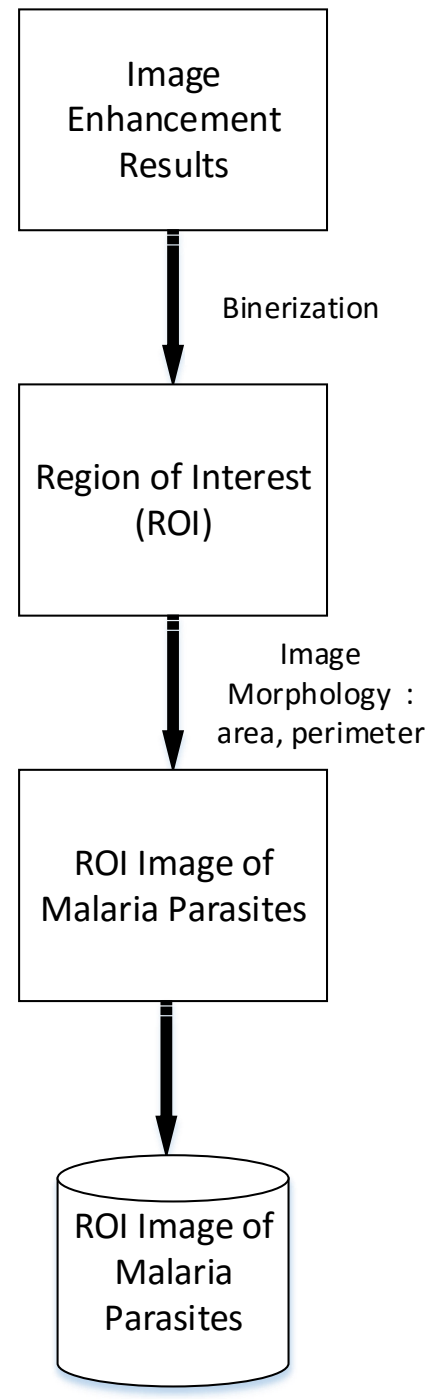

Figure 1. Model for the development of the Malaria Parasite ROI process

Figure 1. Explaining the development model of the ROI process for malaria parasites starting from image enhancement results, the region of interest, ROI image of malaria parasites and ROI image of malaria parasites stored.

\subsection{Image Enhancement Results}

Research that has been done before with the results of image improvement using PSNR and MSE for the evaluation of image improvement results, can get the Peak Signal to Noise Ratio (PSNR) and Mean Square Error (MSE) values that are better using contrast stretching with a value of 33,3833 dB and 43.9667 when compared to the three methods used, namely histogram equalization, low pass filter and Gaussian filtering. So in the continuation of this research for the $\mathrm{ROI}$ image the image used is the result of image improvement using contrast stretching.

\subsection{Binarization}

Before entering the ROI stage, binarization is done. The object produced from a digital microscope is a 3D object, assumed with the variable $X$, can be seen in equation 1 [25]. 


$$
X=\left[\begin{array}{l}
X \\
Y \\
Z
\end{array}\right]
$$

3D-generated objects are saved into file forms into 2D, shown in Figure 2.

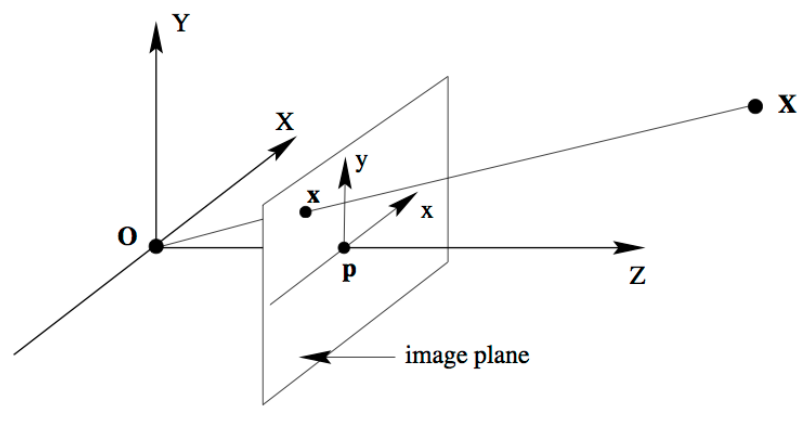

Figure 2. 3D Object to 2D

The formulation results are shown in equation 2 [25].

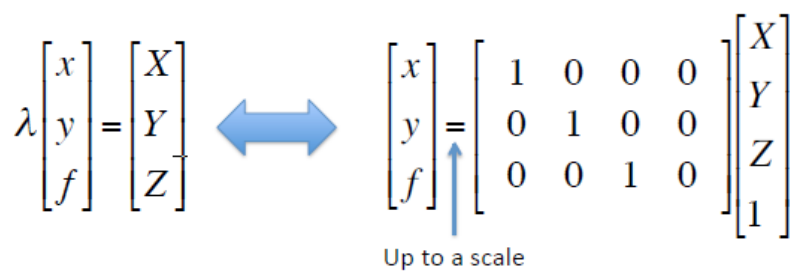

\subsection{Region of Interest (ROI)}

After getting the image of the malaria parasite and the stage, it turned out that the image of the malaria parasite had several objects consisting of normal red blood cells, red blood cells exposed to malaria parasites, platelets, white blood cells and artifacts. So to overcome this problem ROI process is carried out.

At this stage using ROI is by automatic cropping. The challenge in this study where the image of the malaria parasite turns out the position or location of the malaria parasite in the image is not random. Furthermore, to automatically ROI based on the color, it turns out that in the image of malaria parasites there are other objects that have the same color as malaria parasite objects, for example platelets and white blood cells.

In the study [18] erode the area of artifacts which are smaller than infected red blood cells using a disk-shaped element structures. The next step is to do morphological reconstruction to remove elements around the image border. Then using open binary morphology image operations to remove objects that smaller than malaria parasite objects. The research [18] only used one sample type of malaria parasite, vivax with trophozoite stage where the features of vivax malaria had a larger size than red blood cells. The sample image that was shown also had no white blood cell object where the size of the white blood cell was greater than the malaria parasite.

Based on the aforementioned problems, this research conducted an ROI process, namely by automatic cropping where the malaria parasite object is located. 


\subsection{ROI Image of Malaria Parasites}

This stage determines the ROI of the malaria parasite, which is the process of cutting gray level, the cutting process using calculation operations is shown in equation 3 [24].

$$
g(y, x)=\left\{\begin{array}{c}
0, x \leq f_{1} \\
f(y, x), f_{1}<f(y, x)<f_{2} \\
255, x \geq f_{2}
\end{array}\right.
$$

The value of $g$ is polished or cut out for the original intensity from 0 to $f 1$ because it is seen as not containing the value of information or interesting objects. For intensity values from $f 2$ and above, this may only contain noise. The results of the deduction with the values $f 1=50$ and $f 2=150$.

The next stage to distinguish between malaria parasites or non-malaria parasites was carried out the morphological analysis with area and perimeter formula.

The area is the number of pixels of an object indicating the size of the malaria parasite object. The área formula can be seen in equation 4 [26].

$$
\text { Area }=\sum_{x} \sum_{y} f(x, y)
$$

Where $f(x, y)$ is the image of malaria parasites

$f(x, y)=1$, if $f(x, y) \in$ parasitic object,

$f(x, y)=0$, not a parasitic object

Perimeter is the length of the frame produced. Perimeter formula can be seen in equation 5 [27].

$n_{e}$ states the number of even codes

$$
P=n_{e}+\sqrt{2} n_{o}
$$

$n_{o}$ states the number of odd codes

$\mathrm{ROI}$ is taken to ensure that the taken $\mathrm{ROI}$ is the area of the malaria parasite, not having other objects such as platelets, leukocytes, or artifacts. The ROI results are then stored in the image file in jpg format.

After getting ROI results from malaria parasites, the next step is to evaluate. The Bait Method which is the RMSE (Root Mean Square Error). RMSE is as follows [28] :

$$
R M S E \cong \sqrt{\frac{\sigma_{Y}^{2}\left[1-\rho_{X, Y}\right]}{N}\left\{2+\left[1+\rho_{X, Y}\right]\left[\frac{X_{i}-\mu_{X}}{\sigma_{X}}\right]^{2}\right\}}
$$

$$
\begin{array}{ll}
\text { RMSE } & =\text { Root Mean Square Error } \\
\sigma_{Y}^{2} & =\text { Varians Score } Y \\
\rho_{X, Y} & =\text { Correlation between } X \text { and } Y \\
\mathrm{~N} & =\text { the number of data } \\
\mu_{X} & =\text { Average of score } X \\
\sigma_{X} & =\text { Standard deviation of } X \text { score }
\end{array}
$$




\section{RESULTS AND DISCUSSION}

Based on the results of the model that has been designed, the following results of the method and discussion.

\subsection{Region of Interest (ROI) Results}

After the image improvement process is carried out to get a better image quality, the next process is Region of Interest (ROI). Figure 3 shows the part of the image carried out by the Region of Interest (ROI).

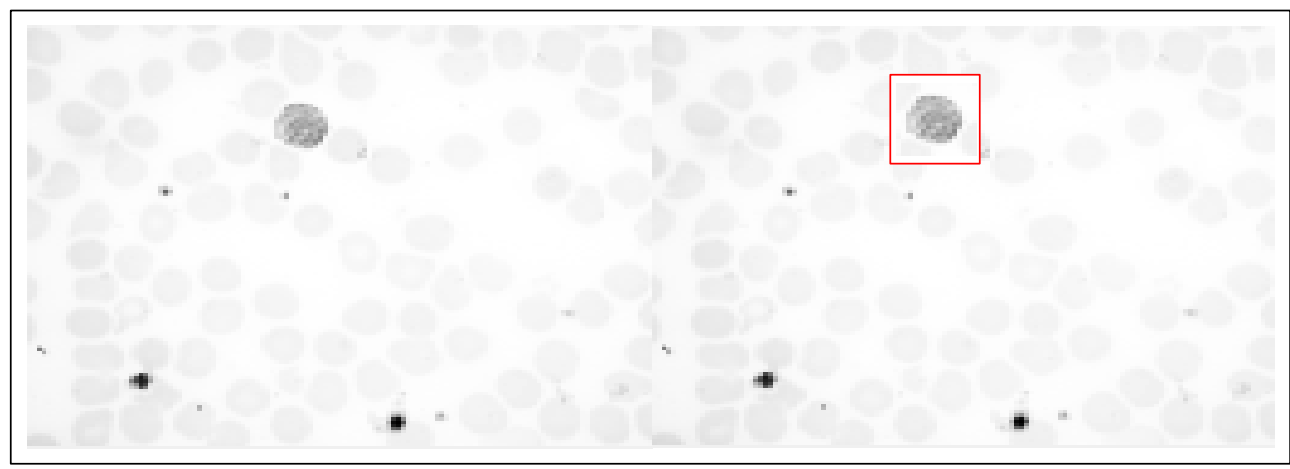

(a)

(b)

Figure 3. (a) Image Improvement Results using Contrast stretching

(b) ROI Image Area

After enhancement done, the test result of RMSE (Root Mean Square Error) is 0.159.

\subsection{Results of Region of Interest (ROI) of Malaria Parasites}

It can be seen that the ROI image produced by automatic cropping is the ROI of malaria parasites, where objects that are not malarias parasites are no longer visible. The results of the Malaria Parasite ROI image can be seen in Figure 4.

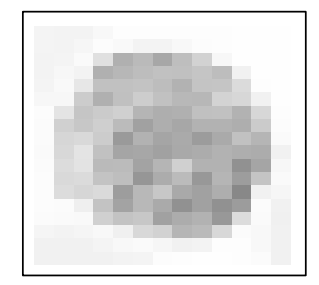

Figure 4. Results of Malaria Parasite ROI Image

After obtaining parasitic ROI results, the next step is tested with the RMSE indicator (Root Mean Square Error). This test is done to see the level of similarity of the image of malaria parasites. The accuracy of the similarities in the image of malaria parasites is indicated by the presence of smaller RMSE values. From the test results with 150 image data using RMSE obtained the average value of RMSE results is 0.075 . The test results show the level of similarity in the parasitic $\mathrm{ROI}$ image approaching the image of the original parasite. 


\section{CONCLUSION}

As known that the previous research proved that the result of image enhancement test used contrast stretching with RMSE from 150 images was 0.159 . The next research concluded that ROI image with automatic cropping can cut malaria parasites object. If found images of red blood cells identified as malaria parasites the image will be truncated and image storage is done, otherwise the image will be truncated but the image is not stored. The number of malaria parasites image with automatic cropping produced are still the same that is 150 images. The test results using RMSE from those images obtained an average of 0.075 , showing the level of similarity of ROI results approaching the desired parasite image.

\section{FUTURE WORKS}

Development of further research is developing models at the segmentation stage. In the segmentation stage, it will compare two segmentation methods, namely Otsu thresholding, and adaptive thresholding. Better results will be used to identify the type of malaria and the stage.

\section{REFERENCES}

[1] http://www.mag.co.id/world-malaria-day-2018/, 2018, World Malaria Day 2018, Tanggal akses 18 Juni 2018

[2] Mediani, M., 2018, Kemenkes: Papua, Papua Barat, dan NTT Endemis Tinggi Malaria, CNN Indonesia, https://www.cnnindonesia.com/nasional/20180423203417-20292975/kemenkes -papua-papua-barat-dan-ntt-endemis-tinggi-malaria, Tanggal akses 18 Juni 2018

[3] Sulistyawati, Rr., L., 2018, 90 Persen Malaria Terjadi di Tempat ini, https://www.republika.co.id/berita/nasional/umum/18/04/23/p7nb31384-90-persenmalaria-terjadi-di-tempat-ini, Tanggal akses 20 Juni 2018

[4] Gitonga, L., Memeu, D.M., Kaduki, K.A., Mjomba, A.C.K. and Muriuki, N.S., 2014, Determination of Plasmodium Parasite Life Stages and Species in Images of Thin Blood Smears Using Artificial Neural Network, Open Journal of Clinic Diagnostics, Scientific Research Publishing Inc

[5] Savkare, S.S. and Narote, S.P., 2015, Automated System for Malaria Parasite Identification, International Conference on Communication, Information \& Computing Technology (ICCICT), India

[6] Anggraini, D., Nugroho, A.S., Pratama, C., Rozi, I.E., Iskandar, A.A. and Hartono, R.N., 2011, Automated Status Identification of Microscopic Images Obtained from Malaria Thin Blood Smears, International Conference on Electrical Engineering and Informatics, Bandung, 17-19 July 2011.

[7] Makkapati, V.V. and Rao, R.M., 2011, Ontology-based Malaria Parasite Stage and Species Identification from Peripheral Blood Smear Images, International Conference of the IEEE, Boston, 30 Agustus - 3 September 2011

[8] Suwalka, I., Sanadhya, A., Mathur, A. and Chouhan, M.S., 2012, Identify Malaria Parasite Using Pattern Recognition Technique, ICCCA, Dindigul, 22-24 Februari 2012

[9] Soni, J., 2011, Advanced Image Analysis based system for automatic detection of malarial Parasite in Blood Images Using Susan Approach, International Journal of Engineering Science and Technology (IJEST), Volume 3 No. 6, Juni 2011

[10] Thung, F. and Suwardi, I. S., 2011, Blood Parasite Identification using Feature Based Recognition, International Conference on Electrical Engineering and Informatics, Bandung 
[11] Kareem, S., Kale, I., Morling, R.C.S., 2012, Automated Malaria Parasite Detection in Thin Blood Films: A Hybrid Illumination and Color Constancy Insensitive, Morphological Approach, IEEE Asia Pasific Conference On, Kaohsiung, 2-5 Desember 2012

[12] Suryawanshi, S. and Dixit V.V., 2013, Comparative Study of Malaria Parasite Detection using Euclidean Distance Classifier \& SVM, International Journal of Advanced Research in Computer Engineering \& Technology (IJARCET), Volume 2 Issue 11, November 2013

[13] Annaldas, S. and Shirgan S.S., 2015, Automatic Diagnosis of Malaria Parasites Using Neural Network and Support Vector Machine, International Journal of Advance Foundation and Research in Computer (IJAFRC), Volume 2, Januari 2015

[14] Komagal, E., Kumar, K.S., Vigneswaran, A., 2013, Recognition And Classification Of Malaria Plasmodium Diagnosis, International Journal of Engineering Research \& Technology (IJERT), Vol. 2 Issue 1

[15] Chavan, S., and Nagmode, M., 2014, Malaria Disease Identification and Analysis Using Image Processing. International Journal of Computing and Technology (IJCAT). Volume 1, Issue 6, July 2014

[16] Banyal, N.A., Surianti, 2016, Dayat A.R, Klasifikasi Citra Plasmodium Penyebab Penyakit Malaria Dalam Sel Darah Merah Manusia Dengan Menggunakan Metode Multi Class Support Vector Machine (SVM), Jurnal Ilmiah Ilkom Volume 8 No. 2 ISSN : 2087-1716

[17] Inayaturrahman, Sunarya, I.M.G., Darmawiguna, I.G.M., 2016, Pengembangan Sistem Klasifikasi Stadium Malaria Plasmodium falciparum pada Citra Mikroskopis Sel, Kumpulan artikel Mahasiswa pendidikan teknik informatika, ISSN : 2252-9063

[18] May, Z., Aziz, S.S.A.M. and Salamat, R., 2013, Automated Quantification and Classification of Malaria Parasites in Thin Blood Smears, IEEE, International Conference on Signal and Irnage Processing Applications (ICSIPA).

[19] Linder, N., Turkki, R., Walliander, M., Martensson, A., Diwan, V., Pietikainen., M., Lundin, M., Lundin, J., Rahtu, E., 2014, A Malaria Diagnostic Tool Based on Computer Vision Screening and Visualization of Plasmodium falciparum Candidate Areas in Digitized Blood Smears, Plos One

[20] Loddo, A., Roberto, C.D., Kocher, M., 2018, Review Recent Advances of Malaria Parasites Detection Systems Based on Mathematical Morphology, Sensors, DOI : 10.3390/s18020513.

[21] Dave, I., Upla, K., 2017, Computer Aided Diagnosis of Malaria Disease for Thin and Thick Blood Smear Microscopic Images. In Proceedings of the 2017 4th International Conference on Signal Processing and Integrated Networks (SPIN), Noida, India, 2-3 February 2017; p. 561

[22] Devi, S., Singha, J., Sharma, M., Laskar, R., 2017, Erythrocyte segmentation for quantification in microscopic images of thin blood smears. J. Intell. Fuzzy Syst., 32, 28472856

[23] Rosado, L., da Costa, J.M.C., Elias, D., Cardoso, J.S., 2016, A review of automatic malaria parasites detection and segmentation in microscopic images. Anti-Infect. Agents 2016, $14,11-22$

[24] Gonzalez, R.C. and Woods, R.E., 2008, Digital Image Processing, Third Edition, PrenticeHall, Inc., USA

[25] Hartley, R. and Zisserman, A., 2003, Multiple View Geometry in Computer Vision, Second Edition, UK: Cambridge University Press.

[26] Das, D., Ghosh, M., Chakraborty, C., Maiti, A.K. and Pal, M., 2011, Probabilistic Prediction of Malaria using Morphological and Textural Information, International Conference on Image Information Processing (ICIIP), IEEE 
Journal of Applied Intelligent System (e-ISSN : 2502-9401 | p-ISSN : 2503-0493)

Vol. 3 No. 2, November 2018, pp. $87-95$

[27] Jahne, B., 2005, Digital Image Processing, $6^{\text {th }}$ revised and extended edition, SpringerVerlag Berlin Heidelberg, New York.

[28] Kolen, M. J. \& Brennan, R. L., 1995, Tes equating: methods and practices. New York: Verlag 